\title{
Bank Competition in Transition Economies: The Case of Albania
}

\author{
Sofika Nazaj, PhD Candidate \\ Head of Corporate Unit, Credins Bank, Tirana Albania \\ sofika.nazaj@bankacredins.com

\section{Dr. Elvin Meka} \\ Department of Finance, Faculty of Economy \\ European University of Tirana, Tirana, Albania \\ elvin.meka@uet.edu.al
}

\section{Doi:10.5901/jesr.2014.v4n3p339}

\begin{abstract}
The Albanian banking system coming from a centralized economy's heritage went through a long transition phase, to be converted, during recent years, into a modern banking system, reflecting the developing market economy in Albania, with many country-specific features. Given such characteristics, and the fact that the new market economy in Albania with still-tobe-consolidated businesses and relatively a big number of banks, with lots of cheap funds to lend, there has been room for a stiff, if rather unfair competition among banks for market share, thus causing a low-quality loan portfolio and liquidity problems in the market. New entrants in the banking market, mainly foreign ones, may have induced too much entry and relatively too many bad loans. Notwithstanding positive effects of banking competition during the entry phase, banks have adopted and seek very high targets on lending, therefore funding risky projects, which failed to produce success stories. When twinning this fact with the actual global and local financial crises, the situation is practically affecting the stability of the banking system in Albania. The paper analyzes and investigates how bank competition affects efficiency of credit allocation, using the historic data of the last decade, and provides some recommendations on improving lending practices, procedures, portfolio diversification, aiming to preserve the stability of the banking system in Albania.
\end{abstract}

Keywords: Credit portfolio, bank competition, NPL - Non-performing loans, market structure.

\section{Introduction}

The Albanian commercial banking system is quite new in its operations within a market economy. Coming out from a centralized economy's heritage, the banking system, as the whole economy, had to undergo radical changes, as it had to be modeled around the new market conditions and principles, following the political changes that happened in Albania and all over the Eastern European countries. Reforming/restructuring the banking system in Albania has taken a relatively long and difficult way, which resulted into many attempts and initiatives to put it into work and functioning in the frame of new market conditions. The long transition phase of the economy has affected the banking system, by experiencing the so-called adverse effect of bank competition into the market.

Schnitzer (1989) stresses that, banking competition affects the efficiency of credit allocation and how the market structure of the banking sector evolves endogenously if entry is not regulated. Bad loans are more likely, the larger the number of banks active in the market. Free entry in turn results in too many banks entering the market, which give rise to the bad loans problem. ${ }^{1}$

Recent developments in the financial global market tend to be globalized, like other business and despite positive effects on that, this trend has exerted more pressure on too many foreign banks to open their branches and subsidiaries in Albania. As a result, 98 per cent of all commercial banks' total capital is coming from abroad (100\% foreign capital or less). Quite a few banks started their operations by 1996, and what is more important, all these banks started to be very aggressive in lending, particularly after 2004 until 2008, just before the outbreak of the latest global financial crisis.

Trying to find the correlation between the theoretical studies and the recent empirical researches, it become easier to understand that, there are contradictions between them. Claessens and Leaven (2003) confirm that "competitiveness

1 Schnitzer, M.: University of Munich and CEPR: "Bank Competition and enterprise restructuring in transition economies" Oct 1998, p.1. 
measure negatively relates to banking system concentration"2

The market concentration by few banks indicates the failure of bank competition and its role to prevent this kind of phenomena. This creates the miscarriage of the system, affecting negatively the normal operating of the Banks. Theoretical literature analyzes it thoroughly the relationship between the competition and the banking system performance and stability.

By analyzing the historical data of the Albanian banking system, in the frame of actual and most recent research, we are trying to draw the right conclusion on the real adverse effect of the bank competition based on the country's specific conditions.

\section{Some Evidences of the Side Effect of Bank Compettion in Albania}

Despite the positive effect for creating a standard and fair market development, bank competition in Albania has also produced some adverse effects and this is very much related to the banking sector. According to Carletti and Hartman (2002), banks and the banking system have a special status, mainly because they are regarded as most vulnerable to instability as other firms or sectors." ${ }^{3}$

In this context, we may presume that bank competition in Albania, despite this special status of banks, is regarded as most vulnerable to instability, in conjunction with the long transition phase from the old banking style of operating as a centralized economy into a free market economy, has relatively more chances not to succeed compare to other countries. Albanian country-specific factors in connection with global factors are both contributing in the failure of bank competition and in its role in preventing the adverse effect in the market. Given the relatively small formal market, there are many banks which are trying to get as quick as possible the access to a limited number of private businesses, which in turn could comply with minimum requirements the lending practices. Typically, 16 commercial banks in Albania competing in the relatively small market are causing a low quality portfolio build-up, which soon could lead to liquidity problems, within the financial system.

Staikouras and wood (2000) points out that the number of banks and branches in a country should be related to its productivity and concentration of banks ${ }^{4}$. As can be easily noted in the Table 1, Table 2 and Chart 1, Chart 2 (attached), despite the fact that most of banks have been already in the market earlier than the year 2000, they have become very active in lending activity after 2004 up to 2008, by competing each other on an intensified lending. Table 1 , and Chart 1 shows clearly banks' concentration in the market.

Following Staikouras \& Wood (2000) findings, we can easily make a simple comparison with the Albanian banking market structure. Greece, as the closest neighbor to Albania, has a lower number of branches, lower productivity and higher concentration, compared to Spain, which has a bigger number of branches, higher productivity and less concentration, but also higher technology investments. When comparing Albania to those countries, there is a quite high concentration, where 5 banks possess more than $75 \%$ of the whole system, out of a total of 16 banks' total assets (see table and chart 1 below), which is similarly to Greece with 83\%, versus Spain with 52\%. The number of branches in Albania is still under both these two countries with 0,17 branches per 1000 inhabitants, versus Greece with 0,24 and Spain with 0,97.

This is typical for the bank competition in Albania, especially because the two former state-owned banks: BKT and Savings Bank (today RZB) possessed most of the assets within the financial sector, during the first wave of the banking activity expansion. Today, both banks still hold 47 per cent of the market. The market structure of banking system in Albania is similar to Greece, which experienced the most severe liquidity problems recently. Nevertheless, countryspecific features make it difficult to draw proper conclusions about the best market structure. Given the similarity with Greek banks, we may dare to think that the Albanian banking system may experience further deterioration of loan portfolio quality.

Denizer (1997) points out that, the review of developments in the banking system suggests that market structure continues to have a significant impact on the conduct and performance of banks, and implicitly on competition. However, observations by themselves are not sufficient to establish a causal link between these parameters, which requires an

\footnotetext{
${ }^{2}$ Claessens, S., and Leaven, L.: "What drives Bank Competition, some international evidence" World bank Policy, working paper 3113 , August 2003, p.8.

${ }^{2}$ Carletti, E., and Hartmann, F.: "What special about Banking" Europian Central Bank", working paper no 146, p. 8, May 2002.

4 Staikouras, C., \& Wood, G.: "Competition and Stability in Euro Area - the Case of Greece and Spain", The City University of Business School, 2000.
} 
empirical investigation. ${ }^{5}$

As Schnitzer (1998) puts it, the problem in Eastern Europe is, however, that firms have not accumulated enough profits to rely on internal financing. Furthermore, institutions like stock markets and bond markets are not sufficiently developed to play a mayor role. This makes outside-financing by banks the only viable alternative. ${ }^{6}$ Similarly as in other Eastern European countries, the businesses in Albania lack sufficient capital to keep the normal balance vs. liabilities, and they are still far from being consolidated and sophisticated to rely on internal financial sources. These businesses lack sufficient managing capabilities. Also, budgeting, forecasting, market research and strategy development for most of the businesses in Albania are still not widely a normal business practice. The Albanian market is not diversified and the businesses were/are typically focused on civil construction and imports of goods, rather than industrial production and exports. So, in the frame of yielding easy money, business administrators invest them into risky project without any precise strategy of using them in an effective way. On the other side, the market was flooded with too-much cheap funds, thus over-funding the economy, from many sources like: remittances, donations, etc., which altogether were far beyond the capacity of the market to absorb them, in the most efficient way. For some banks, which already had cheaper funds especially those with foreign capital, this situation coincided with the blooming phase of lending within the Albanian market, where a lot of cheap foreign funds flowed in. Banks with 100\% Western foreign capital experienced a strong advantage towards the other foreign and local banks at start. Private businesses in Albanian were unprepared to employ/absorb such huge funds in the successful and long-term profitable projects.

All the above-mentioned facts contributed in a poor loan portfolio and an increasing trend of NPL, originated mainly during the period of 2004 - 2008. As it can be easily noticed, (Tab 2 and Graph 2), within this very short period of time, too much cheap funds were flowing into Albania from many sources like: remittances, FDls, which was subsequently accompanied with a sharp increase of credit portfolio and NPLs. The problems of this furious run in lending by banks and borrowing by business become evident with the outbreak of the global financial crisis.

\section{Other Special Indicators within Banking Sector in Albania}

Giving the evidence of the market factors in Albania, it is easy to understand the rush of all commercial banks to grab and fight market share. In this context, banks put high and very aggressive targets on lending, which brought the situation of neglecting basic principals in lending practices. So, the loan portfolio, during this time, was growing faster and the quality deteriorated.

Albania, as most of countries in the region, experienced a consistent trend of assets/collateral reevaluation, which influenced in an additional appetite for banks to increase credit portfolio, in a way of a severe unfair competition, with the argument that the value of collateral is the safety of repaying back, even the low quality loan.

In these circumstances banks paid less attention to lending quality and furthermore, to the overall loan portfolio quality. Banks make insufficient provisions for risk, possibly because they made an optimistic view of collaterals' value, which allows investors to engage in even more speculative activity. ${ }^{7}$ Also, as Nazaj \& Meka (2012) stressed, when it comes to commercial banks, it should be noted that, the lending trend before financial crisis, was perceived by strong competition between commercial banks, which brought poor portfolio quality, caused primarily by: financing risky projects, financing underperforming entrepreneurs, and concentration of lending in construction and real estate sector ${ }^{8}$.

\section{Conclusion}

Failure of the bank's competition, which resulted in a wrong attitude on lending, as twinned with the global financial crisis have caused a high level of NPL s, instability of the banking system, and long downturn of the economic development.

The huge relatively big number of banks operating in market, has given rise to the bad loans problem, especially when these banks do not invest in the screening costs of lending activity.

The banking market structure, the concentration of commercial banks related to country-specific features of each country, and this makes difficult to draw relevant conclusions on the best market structure to be applied.

\footnotetext{
${ }^{5}$ Denizer, C.: "The effects of Financial Liberalization and New bank Entry on Market Structure and Competition in Turkey", Macroeconomics and Growth Development Research Group, Sept. 1997.

${ }^{6}$ Schnitzer, M.: "Bank Competition and enterprise restructuring in transition economies", University of Munich and CEPR, Oct. 1998, p.2.

7 Heffernan, Sh.: "Modern Banking", 2005, Financial Crises Chapter 8.

${ }^{8}$ Nazaj S. \& Meka, E.: "The Trend Of Non-Performing Loans In Albania's Banking Sector - Causes - Challenges \& Recommendations" November 2012.
} 


\section{References}

Schnitzer, M.: "Bank Competition and enterprise restructuring in transition economies", University of Munich and CEPR October 1998.

Claessens, S., \& Leaven, L.: "What Drives Bank Competition, Some International Evidence" World Bank Policy, Working Paper 3113 , August 2003.

Carletti, E., \& Hartmann, F.: "What Special About Banking", European Central Bank, Working Paper No 146, May 2002.

Nazaj, S.\& Meka, E.: "The Trend of Non-Performing Loans in Albania's Banking Sector - Causes - Challenges \& Recommendations" UET 1st International Conference: November 2012.

Denizer, C.: "The effects of Financial Liberalization and New bank Entry on Market Structure and Competition in Turkey", Macroeconomics and Growth Development ResearchGroup, Sept.1997.

Staikouras, C. \& Wood, G.: "Competition and Stability in Euro Area - Tthe Case of Greece and Spain", City University of Business School. 2000.

Heffernan, Sh.: Modern Banking, 2005, Chapter 7 \& 8.

\section{Anex 1}

Table 1. List of the commercial Banks in Albania and their market share as per total assets, September 2012.

\begin{tabular}{|c|l|c|c|c|c|}
\hline No. & $\begin{array}{l}\text { BANKS } \\
\text { NAME }\end{array}$ & $\begin{array}{c}\text { Total Assets } \\
\text { In LEK }\end{array}$ & $\begin{array}{c}\text { in } \% \\
\text { to total }\end{array}$ & $\begin{array}{c}\text { Total Loan } \\
\text { in LEK }\end{array}$ & $\begin{array}{c}\text { Ioan to asset } \\
\text { in } \%\end{array}$ \\
\hline 1 & Raiffeisen Bank - Albania & $323,136,334$ & $28 \%$ & $134,136,033$ & $42 \%$ \\
\hline 2 & Banka Kombëtare Tregtare & $227,102,744$ & $19 \%$ & $86,500,584$ & $38 \%$ \\
\hline 3 & Intesa Sanpaolo Bank - Albania & $138,020,830$ & $12 \%$ & $50,097,011$ & $36 \%$ \\
\hline 4 & Tirana Bank & $94,406,469$ & $8 \%$ & $56,515,232$ & $60 \%$ \\
\hline 5 & Credins Bank & $92,605,448$ & $8 \%$ & $62,548,919$ & $68 \%$ \\
\hline 6 & Alpha Bank - Albania & $73,379,976$ & $6 \%$ & $38,523,319$ & $52 \%$ \\
\hline 7 & Societe General Albania & $60,604,226$ & $5 \%$ & $32,076,576$ & $53 \%$ \\
\hline 8 & National Bank of Greece Al & $42,329,454$ & $4 \%$ & $27,523,373$ & $65 \%$ \\
\hline 9 & ProCredit Bank & $41,161,734$ & $4 \%$ & $23,211,152$ & $56 \%$ \\
\hline 10 & Emporiki Bank - Albania & $32,069,397$ & $3 \%$ & $23,883,626$ & $74 \%$ \\
\hline 11 & Veneto Banka & $15,960,575$ & $1 \%$ & $11,485,324$ & $72 \%$ \\
\hline 12 & First Investment Bank - Albania & $9,833,120$ & $1 \%$ & $5,049,551$ & $51 \%$ \\
\hline 13 & International Commercial Bank & $8,620,359$ & $1 \%$ & $2,503,949$ & $29 \%$ \\
\hline 14 & United Bank of Albania & $6,432,135$ & $1 \%$ & $1,741,423$ & $27 \%$ \\
\hline 15 & Credit Bank of Albania & $1,808,965$ & $0 \%$ & 26,876 & $1 \%$ \\
\hline 16 & Union Bank & n.a & $0 \%$ & $15,877,000$ & \\
\hline TOTAL & & $1,167,471,766$ & & $\mathbf{5 7 1 , 9 1 1 , 0 0 0 , 0 0 0}$ & \\
\hline
\end{tabular}

Source: Bank of Albania

Chart 1. Market share in \% on total assets, of the commercial Banks In Albania, September 2012.

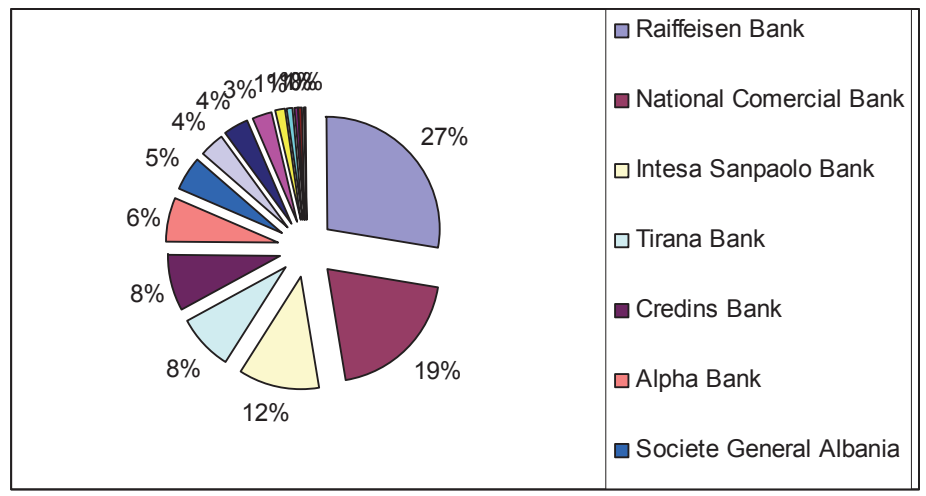




\section{Annex 2}

Chart 2: Market share in \% on total loan of commercial banks In Albania, September 2012.

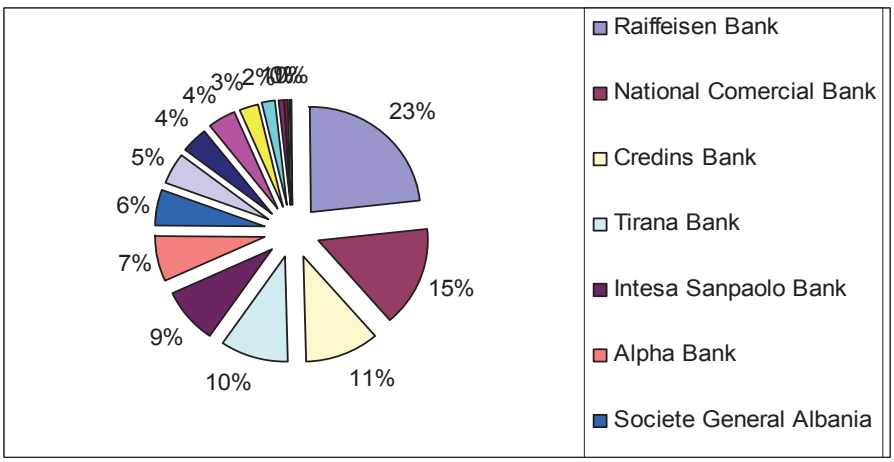

Table 2. Banks performance and the trend of bank lending.

\begin{tabular}{|l|c|c|c|}
\hline Years & $\mathbf{2 0 0 0 - 2 0 0 2}$ & $\mathbf{2 0 0 3 - 2 0 0 5}$ & $\mathbf{2 0 0 6 - 2 0 0 9}$ \\
\hline No of Banks & 11 & 13 & 16 \\
\hline no of Banks lending & 9 & 10 & 16 \\
\hline No agresive lender & 6 & 8 & 16 \\
\hline Portf in billion & 3 & 7 & 31 \\
\hline NPI in billion & - & 0,3 & 2,2 \\
\hline
\end{tabular}

\section{Annex 3}

Table 3: FDI, Stock of portfolio, and Migrant remittances inflows and NPL trends during 2000 to Q1 2012 (ALL million)

\begin{tabular}{|l|c|c|c|c|c|c|c|c|c|c|c|c|c|}
\hline \multicolumn{1}{|c|}{ Years } & $\mathbf{2 0 0 0}$ & $\mathbf{2 0 0 1}$ & $\mathbf{2 0 0 2}$ & $\mathbf{2 0 0 3}$ & $\mathbf{2 0 0 4}$ & $\mathbf{2 0 0 5}$ & $\mathbf{2 0 0 6}$ & $\mathbf{2 0 0 7}$ & $\mathbf{2 0 0 8}$ & $\mathbf{2 0 0 9}$ & $\mathbf{2 0 1 0}$ & $\mathbf{2 0 1 1}$ & $\mathbf{2 0 1 2}$ \\
\hline FDI ACUMULATIVE & 55,700 & 76,500 & 90,000 & 107,800 & 140,200 & 165,900 & 197,300 & 262,000 & 350,800 & 445,000 & 555,900 & 555,900 & 555,900 \\
\hline Stock of portfolio & 47,396 & 14,075 & 35,843 & 48,209 & 60,874 & 112,593 & 172,486 & 259,846 & 377,631 & 437,722 & 490,861 & 566,217 & 572,000 \\
\hline Remittances & 59,800 & 69,900 & 73,357 & 88,875 & 116,067 & 128,970 & 135,947 & 146,802 & 149,504 & 131,848 & 115,602 & 88,700 & 77,200 \\
\hline Total cash inflow & $\mathbf{1 6 2 , 8 9 6}$ & 160,475 & $\mathbf{1 9 9 , 2 0 0}$ & $\mathbf{2 4 4 , 8 8 4}$ & $\mathbf{3 1 7 , 1 4 1}$ & $\mathbf{4 0 7 , 4 6 3}$ & $\mathbf{5 0 5 , 7 3 3}$ & $\mathbf{6 6 8 , 6 4 8}$ & $\mathbf{8 7 7 , 9 3 5}$ & $\mathbf{1 , 0 1 4 , 5 7 0}$ & $\mathbf{1 , 1 6 2 , 3 6 3}$ & $\mathbf{1 , 2 1 0 , 8 1 7}$ & $\mathbf{1 , 2 0 5 , 1 0 0}$ \\
\hline Trend of flowing funds & - & $-1 \%$ & $24 \%$ & $23 \%$ & $30 \%$ & $28 \%$ & $24 \%$ & $32 \%$ & $31 \%$ & $16 \%$ & $15 \%$ & $4 \%$ & $0 \%$ \\
\hline the \% of NPL to tot stock loan & 0 & 0 & 0 & $5 \%$ & $4 \%$ & $3 \%$ & $3 \%$ & $4 \%$ & $6 \%$ & $11 \%$ & $14 \%$ & $19 \%$ & $20 \%$ \\
\hline
\end{tabular}

Source: INSTAT, Bank of Albania

Chart 3 Trend of total total inflowing funds towards the NPL trends during 2000 to Q1 2012 (ALL million)

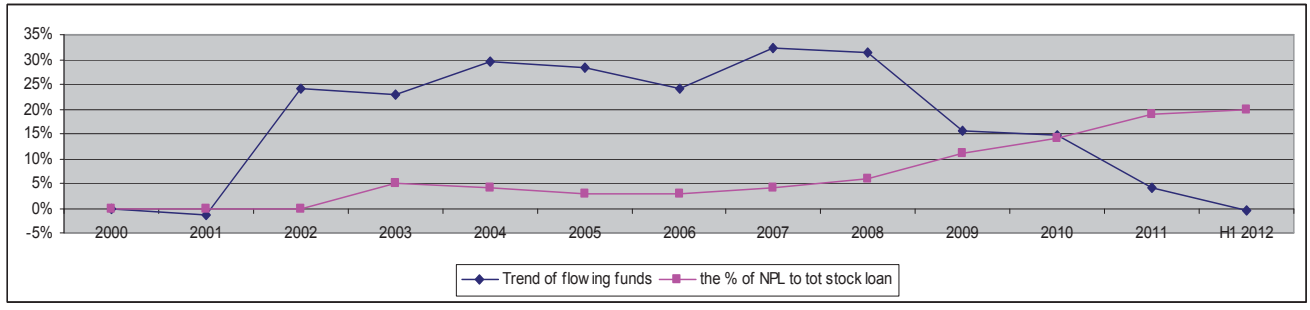


